\title{
Micropropagation of Buttonwood Tree (Conocarpus erectus) through Axillary Shoot Proliferation
}

\author{
Yaser Hassan Dewir ${ }^{1}$ \\ Plant Production Department, College of Food and Agriculture Sciences, \\ King Saud University, P.O. Box 2460, Riyadh 11451, Saudi Arabia; and \\ Department of Horticulture, Faculty of Agriculture, Kafrelsheikh University, \\ Kafr El-Sheikh 33516, Egypt
}

\begin{abstract}
Abdulhakim A. Aldubai
Plant Production Department, College of Food and Agriculture Sciences, King Saud University, P.O. Box 2460, Riyadh 11451, Saudi Arabia; and Agriculture Research and Extension Authority, Sana' a 87148, Yemen
\end{abstract}

\section{Salah El-Hendawy}

Plant Production Department, College of Food and Agriculture Sciences, King Saud University, P.O. Box 2460, Riyadh 11451, Saudi Arabia; and Agronomy Department, Faculty of Agriculture, Suez Canal University, Ismailia 41522, Egypt

\section{Abdullah A. Alsadon \\ Plant Production Department, College of Food and Agriculture Sciences, King Saud University, P.O. Box 2460, Riyadh 11451, Saudi Arabia}

\section{Mayada Kadry Seliem \\ Ornamental and Floriculture Department, Horticulture Research Institute, Antoniades, Alexandria 21599, Egypt}

\section{Yougasphree Naidoo}

School of Life Sciences, University of KwaZulu-Natal, Westville Campus, Private Bag X54001, Durban 4000, South Africa

Additional index words. Combretaceae, button mangrove, shoot proliferation, tissue browning

Abstract. A method for micropropagation of Conocarpus erectus through axillary shoot proliferation is presented. Shoot tips were excised from adult donor tree and cultured for 4 weeks on Murashige and Skoog's (MS) medium supplemented with $3 \mathrm{mg} \cdot \mathrm{L}^{-1}$ gibberellic acid $\left(\mathrm{GA}_{3}\right)$ to induce sprouting of shoots and formation of axillary shoots. Conocarpus erectus shoots were cultured for 6 weeks on MS medium supplemented with different concentrations and combinations of plant growth regulators (PGRs) and proliferation of the shoots was monitored. The type and concentration of cytokinins applied had a significant influence on shoot proliferation responses. Supplementation with 6-benzylaminopurine (BAP) increased the rate of shoot proliferation compared with other cytokinins. The use of BAP in combination with auxins such as indole-3-butyric acid (IBA) and naphthalene acetic acid (NAA) resulted in an increased number of shoots per explant compared with treatment with BAP alone. A combination of $2 \mathrm{mg} \cdot \mathrm{L}^{-1}$ BAP and $0.5 \mathrm{mg} \cdot \mathrm{L}^{-1} \mathrm{IBA}$ produced the highest number of axillary shoots (7.8 shoots/explant). The best rooting medium was full-strength MS medium supplemented with $1 \mathrm{mg} \cdot \mathrm{L}^{-1} \mathrm{IBA}$; this treatment yielded $80 \%$ rooting with an average of 3.5 roots per plantlet. All regenerated plantlets were successfully acclimatized to greenhouse conditions.

The buttonwood tree or button mangrove ( $C$. erectus; Combretaceae) is an evergreen tree that is capable of reaching

\footnotetext{
Received for publication 16 Feb. 2018. Accepted for publication 16 Mar. 2018

The authors extend their appreciation to the Deanship of Scientific Research at King Saud University for funding this work through research group No. (RGP-1438-012) and the Researchers Support \& Services Unit (RSSU) for their technical support. ${ }^{1}$ Corresponding author. E-mail: ydewir@hotmail. com or ydewir@ksu.edu.sa.
}

soft foliage. The wood of $C$. erectus can be used as a fuel for cooking (e.g., smoking meats) and for production of charcoal, and has the potential to be exploited as a farm forestry tree for its fodder and timber uses (Ellison and Farnsworth, 1996; Hernandez and Espino, 1999). Pruning wastes from the trees have also been used to manufacture wood reinforced cement composites (Nasser et al., 2016). Addition of Conocarpus biochar to coarse-textured soils has been reported to improve soil hydroproperties (Ibrahim et al., 2017) and can also be used as a soil amendment for reducing heavy metal availability and uptake by maize (Zea mays) plants (Al-Wabel et al., 2015) and to enhance productivity in tomatoes (Lycopersicon esculentum) in salt-affected sandy soils under arid conditions (Usman et al., 2016). Conocarpus erectus has been used as traditional medicine for diabetes, diarrhea, and fever (Irvin, 1961) and has antioxidative and antibacterial properties (Abdel-Hameed et al., 2012; Ayoub, 2010). The pharmacognostic characteristics and biological activities of $C$. erectus have been reviewed (Bashir et al., 2015).

Conventional propagation of $C$. erectus is achieved through cuttings (Bush and Morton, 1969), although it is feasible to use seeds. However, although seed production may be high, many of the seeds are aborted or do not germinate (Tomlinson, 1986) and seed viability has been estimated as $<12 \%$ (Hernandez and Espino, 1999; Kass et al., 2007). During the dry season, fewer than 5\% of seeds germinated and only $1.6 \%$ of seedlings survived to flower after 25-28 months (Hernandez and Espino, 1999). An alternative approach to propagate $C$. erectus might be through tissue culture techniques that can facilitate the rapid production of propagules from species that are difficult to propagate using conventional techniques. This approach has developed rapidly in recent years and has been applied to a wide range of plant species of importance to the horticultural industry. Although $C$. erectus is of economical and medicinal importance, to our knowledge, tissue culture techniques has not been used to propagate this species. The aim of this study was to develop in vitro propagation of $C$. erectus through axillary shoot proliferation.

\section{Materials and Methods}

Plant material, surface disinfection, and culture establishment. Shoot tips, 3-5 cm long, were taken from adult buttonwood tree $(\approx 10$ year old $)$ at the reproductive stage (Fig. 1A). Explants were defoliated, washed under running tap water, and dipped in an antioxidant solution (1 g. $\mathrm{L}^{-1}$ ascorbic acid and $0.5 \mathrm{~g} \cdot \mathrm{L}^{-1}$ citric acid) for $10 \mathrm{~min}$. The explants were then rinsed three times with running tap water, disinfected for $6 \mathrm{~min}$ in a $0.1 \%(\mathrm{v} / \mathrm{v})$ mercuric chloride solution, and then for $6 \mathrm{~min}$ in $20 \%(\mathrm{v} / \mathrm{v})$ commercial chlorox ${ }^{\mathrm{TM}}(5.2 \%$ sodium hypochlorite $)$ 
solution containing two to three drops of Tween 20 (polyoxyethylene-sorbitan monolaurate). After rinsing three times with sterile distilled water, the explants were cultured for 4 weeks on MS (Murashige and Skoog, 1962) medium containing $3.0 \mathrm{mg} \cdot \mathrm{L}^{-1} \mathrm{GA}_{3}$ and $1 \mathrm{~g} \cdot \mathrm{L}^{-1}$ activated charcoal (Sigma-C6289; Sigma-Aldrich, Poole, UK) for shoot proliferation; MS medium without $\mathrm{GA}_{3}$ served as a control.

Culture conditions. All media were supplemented with $3 \%(\mathrm{w} / \mathrm{v})$ sucrose and solidified with $0.8 \%(\mathrm{w} / \mathrm{v})$ agar-agar. Plant growth regulators were added before autoclaving. The medium was adjusted to pH 5.7 before autoclaving at $121{ }^{\circ} \mathrm{C}$ for $20 \mathrm{~min}$. The cultures were incubated at $25 \pm 2{ }^{\circ} \mathrm{C}$ under a 16 -h photoperiod provided by cool-white fluorescent lights at $35 \mu \mathrm{mol} \cdot \mathrm{m}^{-2} \cdot \mathrm{s}^{-1}$ photosynthetic photon flux density (PPFD).

Axillary shoot proliferation. Conocarpus erectus axillary shoots $(2-3 \mathrm{~cm}$ with three to four nodes) were cultured on MS medium supplemented with different concentrations of BAP $\left(0,0.1,0.5,1\right.$, and $\left.2 \mathrm{mg} \cdot \mathrm{L}^{-1}\right)$, kinetin $\left(0,1,2,4\right.$, and $\left.6 \mathrm{mg} \cdot \mathrm{L}^{-1}\right)$, thidiazuron (TDZ; $0,0.1,0.5,1$, and $\left.1.5 \mathrm{mg} \cdot \mathrm{L}^{-1}\right)$, NAA $(0,0.1$, 0.5 , and $\left.1.0 \mathrm{mg} \cdot \mathrm{L}^{-1}\right)$, and IBA $(0,0.1,0.5$, and $\left.1.0 \mathrm{mg} \cdot \mathrm{L}^{-1}\right)$. Shoot growth and proliferation responses in terms of number of axillary shoots per explant, shoot length, and fresh weight of whole explants were recorded after 6 weeks of culture. All measurements were obtained from 10 randomly chosen shoots.

In vitro rooting and acclimatization. Shoots $(2-3 \mathrm{~cm})$ were used for rooting in full- or half-strength MS basal medium supplemented with $0,0.5$, or $1.0 \mathrm{mg} \cdot \mathrm{L}^{-1} \mathrm{IBA}$ or NAA. The effects of varying sucrose concentration $\left(10,30\right.$, and $\left.50 \mathrm{~g} \cdot \mathrm{L}^{-1}\right)$ and activated charcoal $\left(0\right.$ and $\left.1.5 \mathrm{~g} \cdot \mathrm{L}^{-1}\right)$ on rooting were also investigated. Rooting parameters were recorded after 4 weeks in culture from 10 plantlets. The regenerated plantlets were transplanted into culture plastic pots $(10 \mathrm{~cm}$ in diameter) filled with a sterilized mixture of peatmoss and perlite (1:1). The plantlets were grown in a growth chamber for 4 weeks before transfer to the greenhouse.
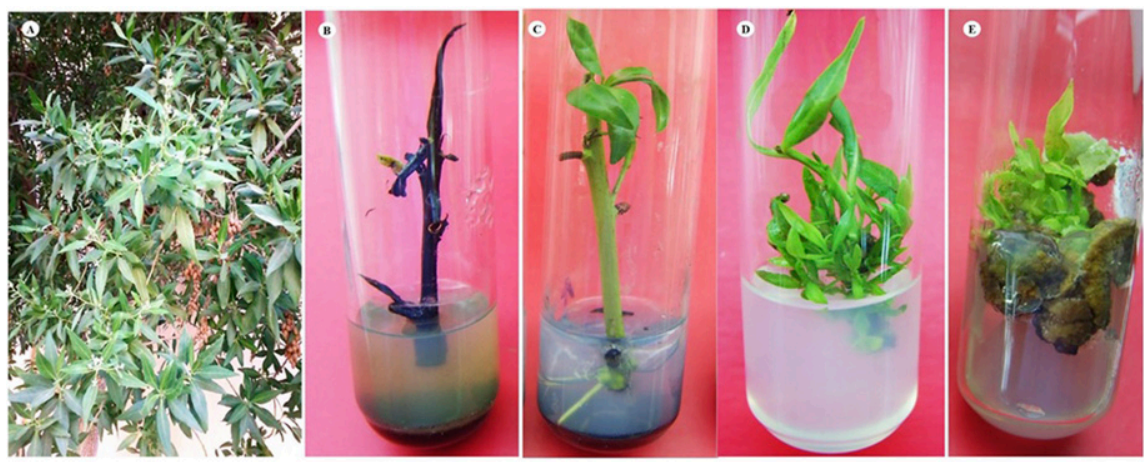

Fig. 1. Establishment of aseptic culture and shoot proliferation of Conocarpus erectus. (A) In situ C. erectus tree, (B) oxidative browning, and (C) culture initiation after 1 week of culture on Murashige and Skoog's (MS) medium supplemented with $3 \mathrm{mg} \cdot \mathrm{L}^{-1}$ gibberellic acid; (D) shoot proliferation after 6 weeks of culture on MS medium supplemented with $2 \mathrm{mg} \cdot \mathrm{L}^{-1}$ 6-benzylaminopurine and $0.5 \mathrm{mg} \cdot \mathrm{L}^{-1}$ indole-3-butyric acid and (E) abnormal morphology of proliferated shoots after 6 weeks of culture on MS medium supplemented with $1.5 \mathrm{mg} \cdot \mathrm{L}^{-1} \mathrm{TDZ}$.
The environment in the growth chamber was adjusted to a $25 \pm 2{ }^{\circ} \mathrm{C}$ air temperature, $50 \%$ to $60 \%$ relative humidity, and $100 \mu \mathrm{mol} \cdot \mathrm{m}^{-2} \cdot \mathrm{s}^{-1}$ PPFD with a $16-\mathrm{h}$ photoperiod using halide lamps.

Experimental design and data analysis. The experiments were performed using a completely randomized design. Data on rooting were expressed as percentages and then arcsine transformed before analysis (Compton, 1994). All data were subjected to Duncan's multiple range test and analysis of variance using the SAS program Version 6.12 (SAS Institute, Inc., Cary, NC).

\section{Results and Discussion}

Establishment of $C$. erectus aseptic culture. Oxidative browning was a major problem during the initiation of culture of C. erectus shoot tips (Fig. 1B). Tissue browning occurs because of the accumulation and subsequent oxidation of phenolic compounds in the tissue and in the culture medium (Krishna et al., 2008; Uchendu et al., 2011). Oxidative browning causes slow growth, low regeneration, and eventually leads to cell/tissue or plant death (Krishna et al., 2008; Panaia et al., 2000) and has been reported to hinder the establishment of cultures in several woody plant species such as Platanus occidentalis (Tao et al., 2007) and Arbutus unedo (ElMahrouk et al., 2010). In the present study, soaking of explants in an antioxidant solution, the addition of activated charcoal to the medium, and avoiding the use of ethanol during surface disinfection prevented tissue browning (Fig. 1C; data not presented). Activated charcoal is an adsorbent that binds phenolic compounds and renders them less toxic (Thomas, 2008). The use of antioxidant solutions has been employed to reduce or prevent browning in plant tissue cultures (Tao et al., 2007; Toth et al., 1994; Uchendu et al., 2011). Conocarpus erectus

Table 1. Effect of cytokinins type and concentration on axillary shoot proliferation and growth of Conocarpus erectus after 6 weeks in culture.

\begin{tabular}{|c|c|c|c|}
\hline Cytokinins $\left(\mathrm{mg} \cdot \mathrm{L}^{-1}\right)$ & Shoots (no./explant) & Shoot length $(\mathrm{cm})$ & Fresh wt per explant $(\mathrm{g})$ \\
\hline 0.1 & $2.2 \mathrm{~cd}$ & $3.2 \mathrm{abcd}$ & $0.46 \mathrm{~b}$ \\
\hline 0.5 & $2.7 \mathrm{bc}$ & $3.0 \mathrm{bcd}$ & $0.29 \mathrm{~b}$ \\
\hline 2.0 & $4.0 \mathrm{a}$ & $3.1 \mathrm{abcd}$ & $0.40 \mathrm{~b}$ \\
\hline \multicolumn{4}{|l|}{ Kinetin } \\
\hline 1.0 & $1.0 \mathrm{e}$ & $3.3 \mathrm{abc}$ & $0.28 \mathrm{~b}$ \\
\hline 6.0 & $1.0 \mathrm{e}$ & $2.8 \mathrm{cde}$ & $0.22 \mathrm{~b}$ \\
\hline \multicolumn{4}{|l|}{ TDZ } \\
\hline 0.1 & $3.2 \mathrm{ab}$ & $2.4 \mathrm{ef}$ & $1.75 \mathrm{a}$ \\
\hline 0.5 & $2.6 \mathrm{bcd}$ & $2.1 \mathrm{f}$ & $2.04 \mathrm{a}$ \\
\hline 1.0 & $2.0 \mathrm{~cd}$ & $2.3 \mathrm{ef}$ & $1.81 \mathrm{a}$ \\
\hline 1.5 & $1.7 \mathrm{de}$ & $2.2 \mathrm{ef}$ & $1.86 \mathrm{a}$ \\
\hline \multicolumn{4}{|l|}{ Significance } \\
\hline
\end{tabular}

${ }^{\mathrm{z}}$ Values followed by the same letter in the same column are not significantly different at $P \leq 0.05$ level, according to Tukey's range test.

NS, ${ }^{*}, * *, * * *$ Not significant or significant at $P \leq 0.05,0.01$, and 0.001 , respectively.

$\mathrm{PGRs}=$ plant growth regulators; $\mathrm{BAP}=6$-benzylaminopurine; $\mathrm{TDZ}=$ thidiazuron . 

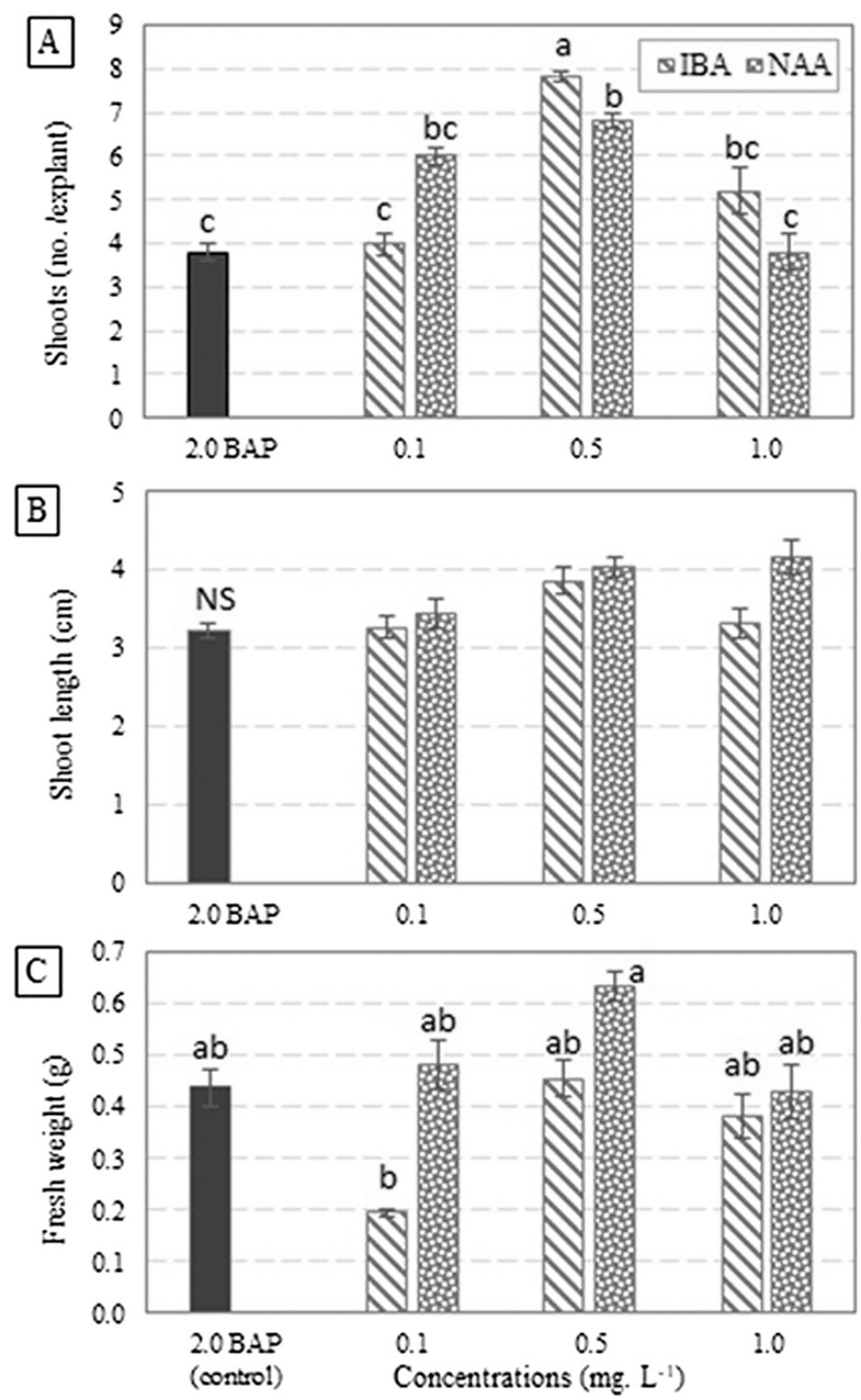

Fig. 2. Shoot proliferation and growth of Conocarpus erectus as affected by combination of $2 \mathrm{mg} \cdot \mathrm{L}^{-1}$ 6-benzylaminopurine (BAP) with indole-3-butyric acid (IBA) and naphthalene acetic acid (NAA) at $0.1,0.5$, and $1.0 \mathrm{mg} \cdot \mathrm{L}^{-1}$ after 6 weeks in culture. (A) Number of shoots, (B) shoot length, and (C) fresh weight.

explants developed axillary shoots on MS medium without PGRs but addition of 3 $\mathrm{mg} \cdot \mathrm{L}^{-1} \mathrm{GA}_{3}$ accelerated their proliferation and growth. The proliferating shoots were healthier and had no browning compared with shoots on medium without $\mathrm{GA}_{3}$ (data not presented). $\mathrm{GA}_{3}$ has been reported to regulate expression of the gene for phenylalanine ammonia-lyase (PAL; EC 4.3.1.5) and to reduce the activity of the PAL enzyme; as a consequence, the addition of
$\mathrm{GA}_{3}$ to the medium was found to reduce browning in Phalaenopsis tissue culture (Zhou et al., 2009). A novel approach to reduce oxidative browning was described in culture of Artemisia annua through the incorporation of an inhibitor of PAL activity, 2-aminoindan-2-phosphonic acid, into the culture medium (Jones and Saxena, 2013).

Axillary shoot proliferation. Axillary shoot proliferation, shoot length, and fresh weight of $C$. erectus explants were significantly influenced by cytokinins type and concentration (Table 1; Fig. 1D and E). Supplementation of medium with 1.0 and $2.0 \mathrm{mg} \cdot \mathrm{L}^{-1} \mathrm{BAP}$ induced the highest number of axillary shoots (3.5 and 4 per explant, respectively) compared with other treatments. Kinetin did not stimulate shoot proliferation. MS medium without PGRs had the lowest number of shoots, smallest shoot lengths, and lowest fresh weight per explants. In general, BAP had a greater effect than TDZ or kinetin for shoot proliferation, whereas $4 \mathrm{mg} \cdot \mathrm{L}^{-1}$ kinetin resulted the greatest shoot lengths (Table 1). The superiority of BAP over other cytokinins for the induction of shoot proliferation in culture has been demonstrated previously in other woody plant species, including Pittosporum napaulensis (Dhar et al., 2000) and Lessertia frutescens (Shaik et al., 2010), and in other members of the family Combretaceae such as Terminalia arjuna (Pandey et al., 2006) and Terminalia bellerica (Dangi et al., 2014). Conocarpus erectus shoots cultured on medium containing $0.1 \mathrm{mg} \cdot \mathrm{L}^{-1} \mathrm{TDZ}$ produced an average of 3.2 shoots per explant; however, the rate of proliferation was reduced with increasing TDZ concentration (Table 1). TDZ has been shown to be an effective and potent synthetic cytokinin for shoot organogenesis and morphogenesis in many plant species, including woody plants (Heutteman and Preece, 1993; Murthy et al., 1998). However, in the present study, TDZ was not effective for shoot proliferation in C. erectus; indeed, abnormal morphology and stunted growth was associated with all TDZ treatments. Calluses also formed at the base of proliferating shoots. TDZ has been shown to be ineffective in plant species such as Spathiphyllum cannifolium (Dewir et al., 2006) and Fraxinus excelsior (Mitras et al., 2009), i.e., it has species specific effects. The abnormalities induced by TDZ depended on the concentration and the duration of treatment. Various BAP and IBA or NAA combinations were tested for induction of axillary shoots (Fig. 2A-C), and the results indicated that $\mathrm{MS}$ medium containing $2.0 \mathrm{mg} \cdot \mathrm{L}^{-1} \mathrm{BAP}$ and $0.5 \mathrm{mg} \cdot \mathrm{L}^{-1} \mathrm{IBA}$ had the highest rate of shoot proliferation (7.8 shoots per explant) compared with other combinations. It has been reported that combination of BAP and auxins may result in a synergistic increase in shoot proliferation, as in woody plant species, including T. arjuna (Pandey et al., 2006), A. unedo (El-Mahrouk et al., 2010), and L. frutescens (Shaik et al., 2010).

In vitro rooting and acclimatization. Varying medium strength and auxin concentrations significantly influenced rooting of $C$. erectus (Table 2 ). The best rooting medium was full-strength MS supplemented with $1 \mathrm{mg} \cdot \mathrm{L}^{-1}$ IBA; this treatment induced root formation in $80 \%$ of the explants with an average of 3.5 roots per explant and an average root length of $5.9 \mathrm{~cm}$ (Table 2; Fig. 3A). No rooting occurred in full-strength MS medium without 
Table 2. Effect of medium salt strength and auxin concentrations on rooting of Conocarpus erectus after 4 weeks in culture.

\begin{tabular}{|c|c|c|c|c|c|c|}
\hline \multirow[b]{2}{*}{ Medium salt strength } & \multicolumn{2}{|c|}{ Auxins $\left(\mathrm{mg} \cdot \mathrm{L}^{-1}\right)$} & \multirow[b]{2}{*}{ Rooting (\%) } & \multirow[b]{2}{*}{ Roots (no./explant) } & \multirow[b]{2}{*}{ Root length $(\mathrm{cm})$} & \multirow[b]{2}{*}{ Fresh wt per plantlet (g } \\
\hline & IBA & NAA & & & & \\
\hline \multirow{3}{*}{ Full strength } & 0.5 & 0.0 & $30 \mathrm{~d}$ & $3.2 \mathrm{ab}$ & $4.4 \mathrm{abc}$ & $0.737 \mathrm{bc}$ \\
\hline & 1.0 & 0.0 & $80 \mathrm{a}$ & $3.5 \mathrm{a}$ & $5.9 \mathrm{a}$ & $0.901 \mathrm{ab}$ \\
\hline & 0.0 & 1.0 & $40 \mathrm{c}$ & $2.0 \mathrm{bc}$ & $3.0 \mathrm{c}$ & $1.0914 \mathrm{a}$ \\
\hline \multirow[t]{3}{*}{ Half strength } & 0.0 & 0.0 & $20 \mathrm{e}$ & $1.2 \mathrm{c}$ & $3.3 \mathrm{c}$ & $0.359 \mathrm{~d}$ \\
\hline & 0.5 & 0.0 & $40 \mathrm{c}$ & $1.6 \mathrm{c}$ & $5.4 \mathrm{ab}$ & $0.501 \mathrm{~cd}$ \\
\hline & 0.0 & 1.0 & $60 \mathrm{~b}$ & $3.8 \mathrm{a}$ & $4.0 \mathrm{abc}$ & $0.868 \mathrm{ab}$ \\
\hline \multicolumn{7}{|l|}{ Significance } \\
\hline Medium salt strength & & & $* * *$ & NS & NS & $* *$ \\
\hline Auxin type & & & $* * *$ & NS & $* * *$ & * \\
\hline Auxin concentration & & & $* * *$ & NS & ** & $*$ \\
\hline
\end{tabular}

${ }^{\mathrm{z}}$ Values followed by the same letter in the same column are not significantly different at $P \leq 0.05$ level, according to Tukey's range test.

NS, ${ }^{*}, * *, * * *$ Not significant or significant at $P \leq 0.05,0.01$, and 0.001 , respectively.

$\mathrm{IBA}=$ indole-3-butyric acid; NAA $=$ naphthalene acetic acid.

auxins, whereas half-strength MS medium resulted in $20 \%$ rooting, indicating that a reduced salt concentration stimulated rooting. Improved rooting under reduced salt concentrations has been suggested to be due to the reduction in nitrogen content rather than a change in osmotic potential (Hyndman et al., 1982). Auxin type and concentration significantly influenced the rate of rooting, the average number of roots, and explant fresh weight. Higher concentrations of auxins $\left(\geq 1 \mathrm{mg} \cdot \mathrm{L}^{-1}\right)$ proved unfavorable to rooting because of callus formation at shoot bases. Low rooting ability is a limiting factor in the micropropagation of woody plant species (Dewir et al., 2016; Nemeth, 1986). Our results confirm previous findings on in vitro rooting of Parkia timoriana (Thangjam and Sahoo, 2012) and Syzyigium cordatum (Dewir et al., 2011) in which rooting was dependent on medium strength, and the type and concentration of auxins. In an attempt to increase the rate of rooting in C. erectus, different sucrose concentrations and application of activated charcoal were tested; none of the tested treatments increased the rate of rooting (data not presented). A high sucrose level (5\%) reduced the rate of rooting (to $40 \%$ ), whereas a $1 \%$ sucrose concentration did not alter the rate of rooting. The addition of activated charcoal to the rooting medium did not increase the rate of rooting; however, it did enhance early root initiation, which was observed after $7 \mathrm{~d}$ of culture (Fig. 3B; data not presented). This effect of activated charcoal might be a result of its ability to irretrievably adsorb inhibitory composites in the culture medium (Thomas, 2008). Regenerated plantlets of C. erectus were acclimatized to ex vitro conditions (Fig. 3C).

In conclusion, an efficient micropropagation protocol for $C$. erectus was developed. Tissue browning was overcome through soaking of explants in antioxidants solution, avoiding the use of ethanol during surface disinfection, and the addition of $1 \mathrm{~g} \cdot \mathrm{L}^{-1}$ activated charcoal and
$3 \mathrm{mg} \cdot \mathrm{L}^{-1} \mathrm{GA}_{3}$ to the initiation medium. The highest rate of shoot proliferation (7.8 shoots per explant) was recorded in MS medium with $2 \mathrm{mg} \cdot \mathrm{L}^{-1} \mathrm{BAP}$ and $0.5 \mathrm{mg} \cdot \mathrm{L}^{-1}$ IBA. Root proliferation occurred in $80 \%$ of explants in full-strength MS medium supplemented with $1 \mathrm{mg} \cdot \mathrm{L}^{-1}$ IBA and successfully acclimatized to ex vitro conditions.

\section{Literature Cited}

Abdel-Hameed, E.S., S.A. Bazaid, M.M. Shohayeb, M.M. El-Sayed, and E.A. El-Wakil. 2012. Phytochemical studies and evaluation of antioxidant, anticancer and antimicrobial properties of Conocarpus erectus L. growing in Taif, Saudi Arabia. European J. Med. Plants 2:93-112.

Al-Wabel, M.I., A.R.A. Usman, A.H. El-Naggar, A.A. Aly, H.M. Ibrahim, S. Elmaghraby, and A. Al-Omran. 2015. Conocarpus biochar as a soil amendment for reducing heavy metal availability and uptake by maize plants. Saudi J. Biol. Sci. 22:503-511.

Ayoub, N.A. 2010. A trimethoxyellagic acid glucuronide from Conocarpus erectus leaves: Isolation, characterization and assay of antioxidant capacity. Pharm. Biol. 48:328-332.

Bailey, L.H. 1976. Hortus third: A concise dictionary of plants cultivated in the United States and Canada. MacMillan Collier MacMillan, New York, NY.

Bashir, M., M. Uzair, and A.C. Bashir. 2015. A review of phytochemical and biological studies on Conocarpus erectus (Combretaceae). Pak. J. Pharm. Res. 1:1-8.

Bush, C.S. and J.F. Morton. 1969. Native trees and plants for Florida landscaping. Florida, Dept. Agr. Consumer Serv. Bul. 193.

Compton, M.E. 1994. Statistical methods suitable for the analysis of plant tissue culture data. Plant Cell Tissue Organ Cult. 37:217-242.

Dangi, B., V. Khurana-Kaul, S.L. Kothari, and S. Kachhwaha. 2014. Micropropagtion of Terminalia bellerica from nodal explants of mature tree and assessment of genetic fidelity using ISSR and RAPD markers. Physiol. Mol. Biol. Plants 20:509-516.

Dewir, Y.H., D. Chakrabarty, E.J. Hahn, and K.Y. Paek. 2006. A simple method for mass propagation of Spathiphyllum cannifolium using an airlift bioreactor. In Vitro Cell. Dev. Biol. Plant 42:291-297.
Dewir, Y.H., H.N. Murthy, M.H. Ammar, S.S. Alghamdi, N.A. Al-Suhaibani, A.A. Alsadon, and K.Y. Paek. 2016. In vitro rooting of leguminous plants: Difficulties, alternatives, and strategies for improvement. Hort. Environ. Biotechnol. 57:311-322.

Dewir, Y.H., N. Singh, S. Mngomezulu, and A.M.K. Omar. 2011. Micropropagation and detection of important triterpenes in in vitro and field grown plants of Syzygium cordatum. J. Med. Plants Res. 5:3078-3083.

Dhar, U., J. Upreti, and I.D. Bhatt. 2000. Micropropagation of Pittosporum napaulensis (DC.) Rehder \& Wilson — a rare, endemic Himalayan medicinal tree. Plant Cell Tissue Organ Cult. 63:231-235.

El-Mahrouk, M.E., Y.H. Dewir, and A.M.K. Omar. 2010. In vitro propagation of adult strawberry tree (Arbutus unedo L.) through adventitious shoots and somatic embryogenesis. Prop. Ornam. Plants 10:93-98.

Ellison, A.M. and E.J. Farnsworth. 1996. Anthropogenic disturbance of Caribbean Mangrove ecosystems: Past impacts, present trends, and future predictions. Biotropica 28:549-565.

Hernandez, C.T. and G. Espino. 1999. Ecologia, produccion y aprovechemiento del mangle Conocarpus erectus L., en Barra de Tecoanapa Guerrero, Mexico. Biotropica 31:121-134.

Heutteman, C.A. and J.E. Preece. 1993. Thidiazuron: A potent cytokinin for woody plant tissue culture. Plant Cell Tissue Organ Cult. 33:105-119.

Hyndman, S.E., P.M. Hasegawa, and D.A. Bressan. 1982. The role of sucrose and nitrogen in adventitious root formation on cultured rose shoots. Plant Cell Tissue Organ Cult. 1:229238.

Ibrahim, A., A.R.A. Usman, M.I. Al-Wabel, M. Nadeem, Y.S. Ok, and A. Al-Omran. 2017. Effects of Conocarpus biochar on hydraulic properties of calcareous sandy soil: Influence of particle size and application depth. Arch. Agron. Soil Sci. 63:185-197.

Irvin, F.R. 1961. Woody plants of Ghana. Oxford Univ. Press, London, UK.

Jones, A.M.P. and P.K. Saxena. 2013. Inhibition of phenylpropanoid biosynthesis in Artemisia annua $\mathrm{L}$.: A novel approach to reduce oxidative browning in plant tissue culture. PLoS One 8: e76802.

Kass, L., R. Hunt, S. Danfort, and T.P. Egan. 2007. Reproductive biology of buttonwood, a polygamous population on San Salvador. Bahamas Naturalist J. Sci. 2:40-49. 

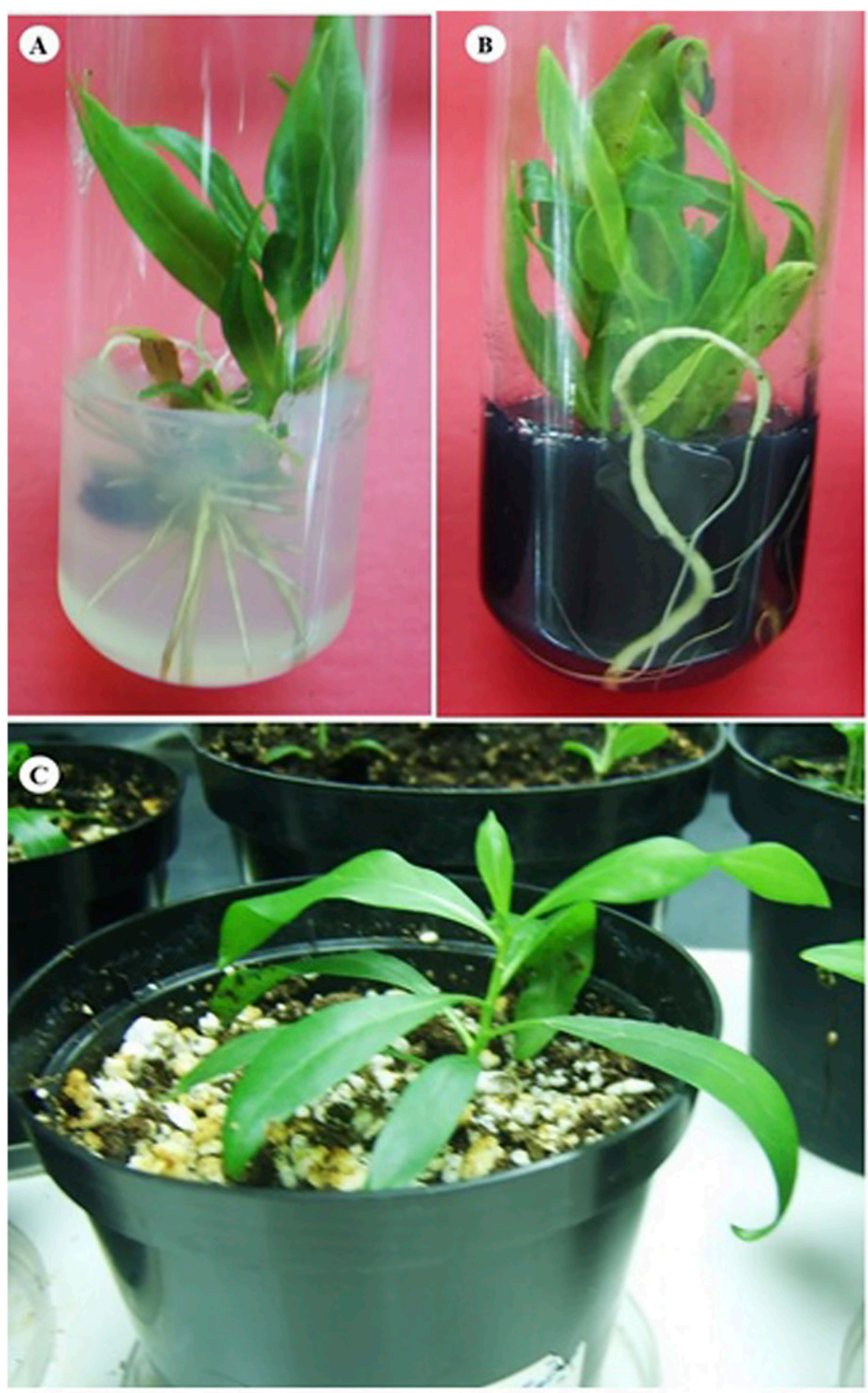

Fig. 3. In vitro rooting and acclimatization of Conocarpus erectus. (A) In vitro-rooted plantlet after 4 weeks of culture on Murashige and Skoog's (MS) medium supplemented with $1 \mathrm{mg} \cdot \mathrm{L}^{-1}$ indole3-butyric acid (IBA), (B) in vitro-rooted plantlet after 4 weeks of culture on MS medium supplemented with $1 \mathrm{mg} \cdot \mathrm{L}^{-1} \mathrm{IBA}$ and $1.5 \mathrm{~g} \cdot \mathrm{L}^{-1}$ activated charcoal, and (C) plantlet after 6-week acclimatization.

Krishna, H., R.K. Sairam, S.K. Singh, V.B. Patel, R.R. Sharma, M. Grover, L. Nain, and A. Sachdev. 2008. Mango explant browning: Effect of ontogenic age, mycorrhization and pre-treatments. Scientia Hort. 118:132138.

Mitras, D., P. Kitin, I. Iliev, D. Dancheva, A. Scaltsoyiannes, M. Tsaktsira, C. Nellas, and
R. Rohr. 2009. In vitro propagation of Fraxinus excelsior L. by epycotyls. J. Biol. Res. 11:3748.

Murashige, T. and F.A. Skoog. 1962. A revised medium for rapid growth and bioassays with tobacco tissue cultures. Physiol. Plant. 15:473479 .

Murthy, B.N.S., S.J. Murch, and P.K. Saxena. 1998. Thidiazuron: A potential regulator of in vitro plant morphogenesis. In Vitro Cell. Dev. Biol. Plant 34:267-275

Nasser, R.A., M.Z.M. Salem, H.A. Al-Mefarrej, and I.M. Aref. 2016. Use of tree pruning wastes for manufacturing of wood reinforced cement composites. Cement Concr. Compos. 72:246256.

Nemeth, G. 1986. Induction of rooting, p. 49-64. In: Y.P.S. Bajaj (ed.). Biotechnology in agriculture and forestry. Vol. 1. Springer-Verlag, New York, NY

Panaia, M., T. Senaratna, E. Bunn, K.W. Dixon, and K. Sivasithamparam. 2000. Micropropagation of the critically endangered Western Australian species, Symonanthus bancroftii (F. Muell.) L. Haegi (Solanaceae). Plant Cell Tissue Organ Cult. 63:23-29.

Pandey, S., M. Singh, U. Jaiswal, and V.S. Jaiswal 2006. Shoot initiation and multiplication from a mature tree of Terminalia arjuna roxb. In Vitro Cell. Dev. Biol. Plant 42:389-393.

Shaik, S., Y.H. Dewir, N. Singh, and A. Nicholas. 2010. Micropropagation and bioreactor studies of the medicinally important plant Lessertia (Sutherlandia) frutescens. S. Afr. J. Bot. 76:180-186.

Tao, F-J., Z-Y. Zhang, J. Zhou, N. Yao, and D-M. Wang. 2007. Contamination and browning in tissue culture of Platanus occidentalis L. For. Stud. China 9:279-282.

Thangjam, R. and L. Sahoo. 2012. In vitro regeneration and Agrobacterium tumefaciensmediated genetic transformation of Parkia timoriana (DC.) Merr: A multipurpose tree legume. Acta Physiol. Plant. 34:1207-1215.

Thomas, T.D. 2008. The role of activated charcoal in plant tissue culture. Biotechnol. Adv. 26:618-631.

Tomlinson, P.B. 1986. The botany of mangroves Cambridge Univ. Press, New York, NY.

Toth, K., T. Haapala, and A. Hohtola. 1994 Alleviation of browning in oak explants by chemical pretreatments. Biol. Plant. 36:511517

Uchendu, E.E., G. Paliyath, D.C. Brown, and P.K Saxena. 2011. In vitro propagation of North American ginseng (Panax quinquefolius L.). In Vitro Cell. Dev. Biol. Plant 47:710-718.

Usman, A.R.A., M.I. Al-Wabel, Y.S. Ok, A. AlHarbi, M. Wahb-Allah, A.H. El-Naggar, M Ahmad, A. Al-Faraj, and A. Al-Omran. 2016. Conocarpus biochar induces changes in soil nutrient availability and tomato growth under saline irrigation. Pedosphere 26:27-38

Zhou, W-L., R-F. Tan, C-J. Xu, Y-Y. Lai, D-Y Chen, and L. Li. 2009. Gibberellic acid inhibits browning, enzyme activity and gene expression of phenylalanine ammonia-lyase in Phalaenopsis leaf explants. Genes Genomes Genomics 3:68-71. 